\title{
Global Cultural Flows and Pedagogic Dilemmas: Teaching in the Global University 'Contact Zone'
}

\author{
Parlo Singh and Catherine Doherty \\ School of Cultural and Language Studies in Education \\ Queensland University of Technology
}

Contact: Parlo Singh and Catherine Doherty

School of Cultural and Language Studies in Education

Faculty of Education

Queensland University of Technology

Victoria Park Road

KELVIN GROVE 4059 AUSTRALIA

Phone: Tel: (w) +61 738643431 (or) +61 738645964

Fax: +61 738643988

Email: p.singh@qut.edu.au, c.doherty@qut.edu.au

This is the authors' version of this work. It was later published as:

Singh, P. \& Doherty, C. (2004). Global Cultural Flows and Pedagogic Dilemmas: Teaching in the Global University ‘Contact Zone’ TESOL Quarterly, 38 (1), 9-42. (IS: 0039-8322).

Copyright (2004) Teachers of English to Speakers of Other Languages 


\title{
Global Cultural Flows and Pedagogic Dilemmas: \\ Teaching in the Global University 'Contact Zone'
}

\begin{abstract}
:
Sites of internationalized education are the result of, and in turn contribute to, the cultural processes of globalization. These sites have created new education contact zones which may pose moral dilemmas for the teachers therein - in particular for the teachers employed in the cultural contact zones of English as a Second Language (ESL), English for Academic Purposes (EAP), and Foundation preparatory programs. This paper reviews theorizations of culture, cultural identity and cultural processes under conditions of globalization, and then analyzes teachers' interview accounts of pedagogic choices in designing and enacting educational programs for international students in the contact zone of the global university. Specifically, it examines the ways in which teachers navigate and manage the dilemmas created between their professional ethic of cultural respect, and the curricula of linguistic/cultural orientation to Western higher education. It is proposed that teachers' different assumptions about the cultural processes of globalization contribute to the construction of a range of strategies and moral positions when managing such dilemmas. Moreover, it is suggested that holistic, tightly bounded notions of culture no longer adequately inform pedagogic practice in these globalized and globalizing sites.
\end{abstract}




\section{Introduction}

The most visible and widely publicized indicator of educational globalization is the increasingly diverse ethnic and linguistic composition of the student population on Western university campuses (Levin, 2001; Luke, 2001). In 2002, international students ${ }^{1}$ comprised $20 \%$ of the total student enrolment in the Australian university sector (Department of Education, Science and Training, 2003; Noonan, 2003). Moreover, approximately $80 \%$ of all international student enrolments in Australian universities were from Asia, with the majority of students (55\%) from South-East Asian countries, namely, Indonesia, Malaysia, Singapore, and Thailand ${ }^{2}$ (Maslen 2002, p.2). Australia now draws more students from Singapore, Malaysia and Indonesia than the United States (McMurtrie, 2001). It has been noted that the vast majority of these students are of Chinese ethnic and linguistic background and predominantly from the newly industrialized countries of South-East Asia ( Nesdale et al., 1995). This predominance of students from South-East Asia has strongly influenced how the Australian higher education sector imagines the educational needs of the 'international student', and consequently designs preparatory curricula and pedagogy for this student cohort.

In general terms, Asian international students travel to Western universities to acquire Western credentials and expertise because these offer greater workplace flexibility and geographic mobility in the global occupational marketplace (Luke, 2001; Rizvi, 2000). The status of English as the emerging lingua franca of the global networked economy has guaranteed Australia a competitive education export position in the Asia-Pacific region. In EAP and Foundation programs, scores in language competence measures such as the International English Language Testing System (IELTS) or the Test of English as a Foreign Language (TOEFL) are used as manageable proxy measures of academic readiness for mainstream university study. Entry and exit levels into the various stages of the articulated pathways into higher education are dictated by English proficiency. Though English serves as the official rubric governing assessment in these programs, the various curricula in the preparatory pathway are also explicitly geared towards developing the culturally suitable demeanours, dispositions and behaviours of a 'Western' academic student. Thus students are offered courses in not only English, but also cultural orientation and study skills.

In this paper, we examine teachers' understandings of culture and cultural identity, and how these understandings may inform moral and ethical decision making in Australian higher education classroom interactions (EAP, ESL and Foundation studies courses). We draw on interview data collected from nine teachers responsible for educating eight classes of students. In the course of the interviews, teachers were asked to critically reflect on video-taped extracts of their own classroom lessons. The selected extracts were indicative of the tensions, conflicts or interactive trouble evidenced in the classroom lesson data collected for the study.

We have organized the paper in three parts. In the first part, we examine new theorizations of culture and cultural identity based on notions of global contact zones, and consider the implications of these new theorizations for conceptualizing pedagogic approaches in EAP, ESL and Foundation preparatory programs. We also review different theorizations of the cultural consequences of globalization, and how these may inform pedagogic designs in global higher education contact zones. The second part of the paper deals specifically with how EAP, ESL and Foundation studies teachers describe strategies for managing the cognitive and moral dilemmas associated with pedagogic work in global contact zones. In the third part, we connect the global with the local, and challenge teachers to critically consider how new theorizations of cultural globalization and global contact zones may assist in the management of moral dilemmas, and inform the design and enactment of pedagogic work.

Given the fluid and fluctuating character of globalization processes, we do not assume that any one pedagogic approach or design is always automatically liberatory or empowering. As globalization processes increasingly unsettle our assumptions about teacher, student and cultural identities, we suggest that communicative relations in such contact zones will need to be re-negotiated, re-worked, and re-made in new and contingent ways exacerbating the 'postmethod condition' referred to by Canagarajah (2002, p.140). What matters increasingly is how culture and cultural identity are evoked, by whom, for what purposes and with what potential consequences in specific locations (see Clifford, 1997). For teachers of EAP, ESL and Foundation studies, it is timely to critically engage with such 
questions because 'globalization changes the conditions in which language learning and language teaching take place’ (Block \& Cameron, 2002, p.2).

\section{Global Contact Zones - New Theorizations of Cultural Identity}

We propose that ESL, EAP, and Foundation preparatory programs can be theorized as global education contact zones (see also Canagarajah, 1997). Contact zones are spatial, temporal locations that have already been constituted relationally and which enter new relations through historical processes of displacement (Clifford 1997, p.7). Location refers to 'an itinerary rather than a bounded site - a series of encounters and translations' in space and time (Clifford 1997, p.11). In these locations or contact zones, people with disparate historical trajectories and cultural $^{3}$ identities 'meet, clash, and grapple with each other, often in highly asymmetrical relations of domination and subordination' (Pratt 1992, p.4). These asymmetrical power relations, are not only historically constituted as the aftermath of colonialism, imperialism and slavery, but are reconstituted and contested in day-to-day pedagogic interactions. These contact zones have been historically constituted in relation to the following types of influences and processes: (1) legacies of Western colonial and neo-colonial practices, (2) recent market driven imperatives of Western higher education as the sector shifts from education as aid to export/trade, (3) the global spread of English language and Western knowledge, and (4) demands of former colonized people for access to dominant language and knowledge resources on their own terms (Canagarajah, 1999). The teachers and students who meet in these contact zones are active agents who produce, co-construct and challenge the design of these programs in and through day-to-day pedagogic interactions. As Clifford (1997, p.3) argues, 'cultural centers, discrete regions and territories, do not exist prior to contacts, but are sustained through them, appropriating and disciplining the restless movements of people and things'. Moreover, teachers and students travel to and from these contact zones via similar circuits or routes. In other words, many EAP, ESL and Foundation studies teachers have travelled to and taught in South-East Asian countries, and many of the students who attend Australian higher education institutions have completed years of English language studies often designed and delivered by teachers with Western credentials. Cultural contact therefore is not a one off event, nor is movement or travel simply one-way.

This theorization of contact zones problematizes notions of static, fixed, bounded socio-cultural wholes as depicted in theories of "acculturation" (with its overly linear trajectory: from culture A to culture B) or "syncretism" (with its image of two clear systems overlaid)' (Clifford, 1997, p.7). Contact zones are spaces of intercultural import-export and of transculturation (Hall, 1996; Pratt, 2002). The metaphor suggests a dyadic relationship, a mutual entanglement of cultural practices and modes of representing cultural identity with contestations and struggles over 'interpretative power' (Kenway \& Bullen, 2003; Pratt, 1999; Papastergiadis, 1997). In other words, contact zones are spaces where 'cultural action, the making and remaking of identities, takes place $\ldots$ along the policed and transgressive intercultural frontiers of nations, peoples, locales' (Clifford 1997, p.7). Stuart Hall (1996, p.251) suggests that 'the two-way cultural traffic characteristic of the contact zones' was evident in the cities of the colonized long before it became a characteristic feature of the cities of the colonizing ${ }^{5}$. In other words, the colonial relation was never simply a one-way flow of ideas from the colonizer to the colonized.

In recent times, Western universities have become zones of escalating cultural contact as increasingly large numbers of students from former colonized nations enrol in these institutions to acquire a Western education. The initial contact zones of ESL, EAP and Foundation studies programs are relatively recent pedagogic innovations designed to accommodate encounters between people with diverse historical trajectories, cultural identities, and linguistic repertoires in Western higher education institutions. Consequently, global education contact zones are 'not only what practitioners are teaching about, but what they are teaching in' (Bizzell, 1994, p.166). These programs appear to be relatively standardised across Western nation states such as the UK, US, Canada, Australia and New Zealand (Levin, 2001). Although academic preparation programs have been designed to improve articulation between overseas school systems and university disciplines (Humfrey, 1999), they appear to be based on notions of acculturation and/or syncretism - concepts of culture that have been challenged in recent years (see Appadurai, 1996; Castells, 1997; Clifford, 1997; Hall, 1996; Pratt, 2002; Shome \& Hegde, 2002). Teachers employed in these programs appear to act as cultural informants socializing nonWestern students into the norms or standards of Western scholarly conduct. For example, Foundation and EAP programs across the Western higher education sector offer at the point of reception into university study a course in English language instruction, academic study skills, and cultural orientation. In addition, Foundation programs provide prerequisite disciplinary specific knowledge. Any difficulties that Asian international students may experience in the cultural contact zones are often 
explained by notions of culture shock, which place the burden of responsibility for adjustment on the individual student. $^{6}$

More recently, however, teachers employed in the Australian higher education sector have been asked to internationalise ${ }^{7}$ curricula and pedagogy. The possibilities for designing pedagogic practices that take account of new theorizations of global cultural contact zones are thus emerging in the higher education sector. EAP, ESL and Foundation studies teachers are potentially at the forefront of this push to internationalise curricula and engage in modes of pedagogy responsive to the changing globalized and globalizing zones of higher education.

\section{New Millennium Cultural Consequences of Educational Globalization}

In broad terms, globalization refers to the compression of space and time (Harvey cited in Burawoy, 2000, p.2), and thus the intensification of social and political relationships and heightened economic competition (Castells, 2000). Distant localities are linked 'in such a way that local happenings are shaped by events occurring many miles away and vice versa' (Giddens 1990, p.64). This connection of the local with the global has been made possible by 'institutional, organizational and technological' capacities that enable social interactions 'in real time or in chosen time, on a planetary scale' (Castells 2000, p.101). Put simply, globalization processes are 'political, technological and cultural, as well as economic' (Giddens 2000, p.28). Political ideas, technological innovations, economic models and influences, as well as cultural resources move rapidly, at times instantly, across the globe. Some theorists, however, have noted that globalization processes are not necessarily new, but rather can be dated back several hundred years (Castells, 2000; Giddens, 2000). However, new millennium globalization processes are characterized by three unique and distinguishing features: firstly, the predominance of symbolic, cultural flows as opposed to earlier material or political exchanges; secondly, the speed and volume of resources flowing across the globe; and thirdly the increasing importance of global terms, or scales, of reference in imagining global-local connections (see Appadurai, 1996; Giddens, 2000; Spring, 2001; Tomlinson, 1999; Waters, 2001). At the same time, however, new millennium globalization processes are experienced in complex, uneven and varied ways by people across different spaces (Giddens 2000, p.22). In other words, globalization is not a consistent or uniform phenomenon.

Our primary concern in this paper is with the cultural consequences of globalization (Holton, 2000) as these are played out in the contact zones of Australian higher education. In particular, we are concerned with the ways in which these new cultural processes continually unsettle our taken-for-granted assumptions about teachers, learners, and appropriate pedagogic strategies in EAP, ESL and Foundation studies courses. We use the term culture to refer to the symbolic resources (language, images, fashion codes, knowledge, political ideologies and so forth) that are increasingly available in their rapid flow across territorial borders, as well as to the ways in which people individually and collectively experience and make sense or meaning of these cultural resources (see Singh, 2004). Globalization

... produces a 'dis-location' of culture, that is, it presents us with a 'cognitive dilemma' because culture is no longer what it used to be or where we might expect it to be. It has become more abstract and imploded ... What looks the same may already be different and what is already different may still look the same. (Shome \& Hegde 2002, p.173)

The term 'global cultural flow' is used to indicate the simultaneous fluid movement and changing meaning of ideas, as well as their location in, and passage through specific historical, linguistic and political contexts (Appadurai, 1996; Spring, 2001). Appadurai (1996) distinguishes between a number of flows or scapes along which cultural or symbolic resources move: (a) ethnoscapes, (b) mediascapes, (c) technoscapes, (d) financescapes, and (e) ideoscapes (Appadurai, 1996, p.46). The suffix -scape refers to the 'fluid, irregular shapes of these landscapes' (Appadurai 1996, p.33). It also indicates that these landscapes are 'deeply perspectival constructs, inflected by the historical, linguistic, and political situatedness of different sorts of actors: nation-states, multinationals, diasporic communities, as well as subnational groupings and movements' (Appadurai 1996, p.33). According to Appadurai (1996, p.35), the global relationship within and between these different scapes or flows 'is deeply disjunctive and profoundly unpredictable'. In other words, the movement of cultural or symbolic resources does not simply follow the logic of economic incentives, nor is it simply constrained by national or supra-national political constraints. Educational sites such as Western universities are intimately involved in, and contribute towards, these global scapes or flows (see Levin, 
2001; Luke, 2001). For example, the business of exporting higher education to international students can be understood as contributing not just to the movement of people ('ethnoscape'), desiring Western symbolic resources ('mediascapes'), but also to flows of capital ('finanscape') and of ideologies ('ideoscape'), mediated and accelerated by electronic technologies (technoscapes) with the various parties participating from motivations that reflect their perspectives and positioning in global flows. Disjunctural flows often produce discordant moments in their intersection, for example, liberal fashion tastes mushrooming in less liberal religious communities, and attendant moral issues.

By contrast, the term 'global culture' is used to denote 'the growing uniformity and homogenization of the world's cultures' (Spring 2001, p.7). This global culture serves as a 'magnet attracting people' to particular ideas 'regarding economic opportunity and consumption' (Spring 2001, p.7). In addition, this dominant global culture is legitimated by recourse to notions of universal standards which often mask dominant/subaltern, ethnocentric bias (Cameron, 2002). For example, consumption of English language (preferably American or British) and Western knowledge goods are increasingly seen as an avenue for upward social mobility in the global economic market place, and particular models of English language curricula and pedagogy dominate the educational market (see Pennycook, 1999a, 1999b).

EAP, ESL and Foundation studies programs can be viewed as part of both the global culture and global cultural flows/scapes of Western higher education. The empirical section of the paper explores the 'new possibilities' of cultural identity formation and communicative practices, as well as the management of 'new anxieties' during discordant moments as the global connects with the local in higher education contact zones.

Given the powerfully disjunctive and irregular character of global cultural flows/scapes, and the emergence of a dominant global culture the debates surrounding the cultural consequences of globalization are diverse and complex. These debates tend to reveal an unresolved argument between three basic positions, namely:

the homogenization thesis, in which globalization leads to cultural convergence; the polarization thesis, which posits cultural wars between Western globalization and its opponent; and finally, the hybridization ... thesis, in which globalization encourages a blending of the diverse set of cultural repertoires made available through cross-border exchange. (Holton 2000, p.141)

The first hypothesis is that the world wide spread of a neo-liberal market economy and the global strategies of big business (including the increasing privatization of education) are likely to homogenize or standardize local cultures). Consumer capitalism has been built upon standardized brand imagery, and the 'sale of dreams of affluence, personal success, and erotic gratification through advertising and the culture industry' (Holton 2000, p.142). This spread of a global consumer culture has been described as Westernization, or more specifically Americanization, 'Coca-Colonization' or 'McDonaldization' (Holton, 2000; Porter \& Vidovich, 2000). The term McWorld has been coined to describe the standardization or homogenization of an American consumer culture - 'a combination of fast food (McDonald's), fast music (MTV), and fast computers (Apple Mac)' - that promises to tie people together 'through the soulless consumption of commodified cultural production' (Barber cited in Holton 2000, p.146). A crucial dimension of the homogenization thesis is the integration of elites with a Western education 'in the functioning of international organizations like the United Nations, the World Bank, and the United Nations Educational, Scientific and Cultural Organization (UNESCO), as well as global corporations' (Holton 2000, p.143). In this sense, a global culture is developed not only via mass-marketing but through the interests and activities of a transnational global elite (Castells, 1997; Holton, 2000; Luke, 2001). The homogenization thesis assumes a dynamic notion of cultural production and dissemination. At the same time however, global cultural production and circulation is in the hands of a transnational Western educated elite. Educational sites may thus be complicit in the homogenizing of different cultures, and also may play a significant role in providing dominant or hegemonic visions of social order to a global elite.

The second hypothesis relating to the cultural consequences of globalization is that Western cultural homogenisation, neo-liberal global economic markets, and Western versions of modernity are likely to be resisted and challenged by various social movements around the world. Anti-globalization movements are likely to be 'multiple, highly diversified, following the contours of each culture, and of 
historical formations of identity' (Castells, 1997, p.2). They are likely to include proactive movements such as environmentalism and feminism, and reactive movements such as Islamic and Christian fundamentalisms. In particular, reactive fundamentalist movements operate through polarization, constructing powerful cultural dichotomies ${ }^{8}$ between their vision of social order, and the current vision of Western globalization. In this perspective, 'the West is seen as the Other, as immoral and pathologically individualistic' (Holton, 2000, p.146). These dichotomising and polarizing tendencies are likely to produce a clash of civilizations: Western, Islamic, Confucian (Huntington, 1997). Teachers, at the front-line of educational globalization, may have to negotiate conflicts between different cultural groups in the classroom (Hafernik, Messerschmitt \& Vandrick, 2002), as well as take account of different versions and histories of modernity in pedagogic engagements.

The third hypothesis relating to the consequences of cultural globalization is hybridisation, and the resultant production of new education programs and pedagogic practices from a synthesis of diverse cultural forms (Castells, 1997). In terms of English language instruction, hybridisation is evidenced in the different types or versions of English that have emerged around the world. As Salman Rushdie (1982, p.8) points out, English, 'no longer an English language, grows from many roots; and those whom it once colonized are carving out large territories within the language for themselves'. Hybrid practices are possible because the global culture of Western education is domesticated, indigenised, or transculturated, to produce innovative patterns which sustain a sense of the local (see Canagarajah, 1999; Luke, 2001; Pratt, 2002; Shome \& Hegde, 2002; Spring, 2001).

The major conceptual advance of the hybridization thesis is that 'cultures have become so intermixed that there is no longer any pure or authentic culture distinct from others' (Holton 2000, p.150). This intermixing of cultures does not simply produce a melting pot or unity of different cultural attributes or parts. Rather, what emerges is the opening of a third space 'within which other elements encounter and transform each other' to produce new cultural forms and identities (Papastergiadis, 1997, p.254). As tradition increasingly loses its hold, and daily life is reconstituted in terms of the dialectical interplay of the local and the global, individuals are increasingly expected and required to negotiate lifestyle choices among a diversity of options (Giddens, 1990). This undermines teachers' ability to know or predict their 'Other' students with any certainty through reproduced categories. Teachers at the frontline of globalization may have to take account of different versions of English, as well as new hybrid constructions of cultural identity, in day-to-day pedagogic encounters. Moreover, Asian international students as 'informed consumers' in the educational marketplace are unlikely to take up Western knowledge uncritically and 'buy into the "West is best" model' (Luke 2001, p.41). Rather, classrooms are likely to be sites of struggle and contestation over the selection and enactment of curricula and teaching strategies.

The unresolved argument between these three theoretical positions highlights the complex and opposed potentials within relations constituting any contact zone, whereby homogenization, polarization or hybridity might result or be perceived, depending on the discourses, intentions and actions of the actors contributing to how the relations are played out. The three positions also highlight the paradoxical processes of cultural globalization. On the one hand, different cultures are commodified as 'temporally and spatially distinct' leading to concerns about cultural and language extinction, as well as hopes for universal standards in terms of educational rights. On the other hand, 'notions of cultural hybridity and flux' are evoked suggesting that it is no longer possible to talk about culture as unique, insular and specialized meaning production by a group of people (Yon, 2000: 113). Thus, higher education teachers are on the one hand expected to commodify versions of Western pedagogy, learning styles, study skills and academic English for consumption by EAP learners, while at the same time invoking enabling notions of cultural hybridity and flux, with the added dimension of being respectful and valuing the cultural diversity students bring with them.

What we would like to explore now is how teachers differently value and manage these competing potentials for their students, while being part of the same processes themselves. In the next section we examine accounts of pedagogic relations in preparatory programs for international students in the contact zone of an Australian university, a site enmeshed in cultural globalization processes.

\section{Cultural Globalization and Pedagogic Dilemmas}

One particularly significant set of moral dilemmas that EAP, ESL and Foundation program teachers have to negotiate is between their professional ethic of cultural respect, and the 'acculturating' imperative of the linguistic/cultural orientation to Western higher education. On the one hand, teachers 
are wary of the charge of doing symbolic violence to the students' cultural heritage by enacting curricula and pedagogy that may be construed as neo-colonial or neo-imperial (Bourdieu, 1992). On the other hand, teachers are expected to inculcate Western academic habits and dispositions, and thus reproduce Western cultural traditions and norms of academic/scholarly conduct (Bourdieu, 1992). In those situations where idealised versions of Western student are promoted in opposition to reified notions of the 'Asian' learner (often linked to Confucian values) (for example, Ballard \& Clanchy 1997), the moral dilemmas and conflicts confronting teachers in everyday pedagogic interactions are likely to intensify (Doherty, 2001). Morality is defined as 'that set of a person's beliefs and understandings which are evaluative in nature: that is, which distinguish ... consciously or unconsciously, between what is right and wrong, good and bad' (Buzzelli \& Johnston, 2002, p.3). A moral dilemma is understood to be 'a dilemma in which the options involve consequences that are both good and bad' (Buzzelli \& Johnston, 2002, p.3). Hafernik et al., (2002) suggest that ESL teachers often have to deal with relativist notions of ethical practice given the diverse cultural backgrounds of the students present in any one classroom. We suggest that the effects of globalization are such as to make even these ascriptions of predictable cultural attributes uncertain and slippery. In this era of globalization, ESL teachers have to negotiate the ethical and moral dilemmas produced between notions of professional care, curricular charter and conditions of globalization, even as these notions and conditions are rapidly changing and morphing into new forms.

How do EAP and Foundation program teachers negotiate and manage these contradictory and ambivalent ${ }^{9}$ pedagogic dilemmas in the cultural 'contact zones' of higher education institutions? One group of researchers suggest that teachers as moral agents often develop patterns or strategies for managing or coping with these moral dilemmas so that they can get on with their day-to-day pedagogic work. Sometimes these patterns or strategies of management are "consciously chosen, deliberate efforts to put social and educational values into practice' (Berlak \& Berlak, 1981, pp.108-109). At other times, teachers' strategies for managing moral dilemmas may be more implicit, the product of 'sheer habit', or 'formed by cultural and social experiences and forces', and/or internal needs and desires (Berlak \& Berlak, 1981, pp.108-109). In these cases, teachers may not have examined the reasons why they choose particular pedagogic strategies or patterns of classroom interaction (Berlak \& Berlak, 1981). Additionally, institutional settings may similarly regulate patterns of resolution by their corporate culture and practices, resourcing and by the degrees of freedom available to teachers with which to enact the curriculum.

This paper draws on interview data that elicits teachers' reflections and elaborations on their videotaped classroom practices to profile the nature of the dilemmas encountered in preparatory or Foundation programs offered by Australian universities to international students. It also examines how teachers' theories of culture and academic learning may construct varied responses to these dilemmas. We paint detailed portraits of pedagogic practice for three teachers from their interview accounts in order to demonstrate a wide range of strategies and of 'patterns of management', and also describe in brief how the other six teachers observed and interviewed were positioned in relation to these patterns. Our purpose is firstly, to demonstrate the variation in responses possible for teachers to manage the dilemmas embedded in these ambivalent educational sites. Secondly, we aim to show how the different responses may constitute different understandings of culture and cultural identity, with possible consequences for the paths taken by international students into mainstream university programs. Thirdly, we offer teachers additional discursive resources for thinking about the moral dilemmas of pedagogic work in these globalized and globalizing spaces.

While we have endeavoured to capture the complexity of teachers' work in these cultural contact zones, our analyses are necessary limited by the amount of time we could spend in each classroom, as well as the nature and length of the interviews. Both of us are members or insiders of the EAP, ESL and Foundation studies professional communities in our various roles as teacher educators and teachers, while one of us has been an ESL student. At the same time, we are not members of the particular university departments and/or classrooms captured in the research study reported in this paper. Consequently, we are also outsiders to this community. Although both insiders and outsiders, we can only ever reflect the world of the teachers who participated in this study 'in fragments of broken mirrors'- there will inevitably be 'missing bits' in these 'slices' of pedagogic practice (Rushdie 1983, p.73). Our objective then, is not to construct rigid, fixed, or static constructions and proclaim that this is the way that these teachers always engage in pedagogic work. Rather we want to use these portraits to critically think about the ways in which different conceptualisations of culture may be strategically deployed to manage moral and cognitive dilemmas, and to design pedagogic strategies. Our objective 
then is to explicitly link the micro practices of pedagogic work and pedagogic dilemmas in contact zones, with the macro processes of cultural globalization. In doing so, we want to clearly take teachers out of their classrooms and show how their day-to-day work intersects with, works against and for, the push-pull-mix processes of globalization. Critical engagement with these issues is important for all teachers employed on the front-line of educational globalization.

\section{An Empirical Case Study: Pedagogic Dilemmas in the Global University Contact Zone}

The analyses reported in this paper draw predominantly on data collected from semi-structured interviews ${ }^{10}$ with nine teachers ${ }^{11}$, as well as the program outlines and marketing materials produced by the case study institution. ${ }^{12}$ Each teacher was interviewed in two stages, and asked to: firstly respond to a set of general questions about curriculum and pedagogy; and secondly to reflect on and articulate their rationale for particular teaching activities or practices observed and video-taped in their own classes. A stimulated recall method (Keith, 1988) was used in the second stage of interviews, whereby teachers viewed a selected episode of one of their video- taped classes, before being asked to elaborate on the design and enactment of specific pedagogic strategies. Stimulated recall interviews using videotaped lessons as the stimulus have been used in studies of teachers' knowledge and decision-making (for example, McMeniman et al., 2000). The choice allows some access to the empirically invisible complexity of teachers' decision-making in action and in context, and grounds accounts of pedagogy in concrete circumstances, thus avoiding generalised, de-contextualised accounts. In this study, particular episodes were selected ${ }^{13}$ because they: foreground issues of cultural difference in the choice of instructional material; provoked observable discomfort or resistance amongst the students; or because the teacher's choice of pedagogic strategy was marked in some way and distinct from the other teachers.

The teachers were encouraged to participate in the study by program administrators, and were selected on the basis of their teaching experience in the field and their willingness to participate in the research process. Only two of the teachers interviewed for the study held continuing or tenured employment positions in the case study institution. The remaining seven teachers worked on consecutive casual employment contracts. This meant that these teachers were only paid for contact teaching hours, and not for lesson preparation or meetings/consultations with colleagues. Wages for casual teaching work in EAP and Foundation programs are not high. Consequently, many of the teachers held several casual employment contracts across a number of institutions.

The eight classes taught by the nine observed teachers ranged from 12 to 26 students, with the vast majority from South East Asia (Thailand, Malaysia, Singapore, East Timor, Indonesia), East Asia (Hong Kong, Taiwan) and the occasional student from the Pacific Islands, Papua New Guinea, Columbia, Mozambique, and Sweden. Students were aged between 18 and 44, with all groups displaying a wide spread of ages. Of the nine teachers observed, only two did not have postgraduate professional qualifications beyond their initial teaching qualification. All nine had substantial crosssectoral teaching experience, ranging from seven to twenty-eight years. Five of the teachers had also taught overseas.

Across the data set, seven of the nine teachers expressed caution about what topics pertaining to sensitive or controversial issues were introduced into the classroom, and how these topics were discussed/negotiated. Two of the teachers did not touch upon the use of controversial topics, beyond recounting how they employ examples of biased statistics in the hope of provoking discussion. One of these teachers talked about using 'my country' topics as a strategy for encouraging student discussion, and avoiding cultural offence. The other teacher talked about 'choosing topics that are non-emotive' but this was in regard to the sensibilities of scholarship students in the company of wealthier, selffunded students. Elsewhere, the same teacher spoke about how her students 'often get horrified' in class discussions of newspaper accounts of their home country. Two of the nine teachers talked explicitly about employing teaching strategies to protect or assuage student sensibilities. One suggested that she mitigated her taste for 'fun' in the classroom in the face of student discomfort. Another claimed 'I try to be aware of some of the things that make them feel uncomfortable... If you have any sensitivity towards the students you do have to try and balance it out a bit'. Four of the teachers suggested that students needed to be explicitly taught via the use of texts that might be considered sensitive or controversial in their home nations. Moreover, they argued that pedagogic models were selected with the explicit intent of eliciting student discussion, debate and articulation of individual opinions, behaviours associated with pedagogy in the Western university. For example, one teacher 
spoke of introducing 'outlandish ideas to try and stimulate them into talking', and another considered that 'you can be understanding but you can't be too soft, ... because that won't help them'.

\section{Portraits of Pedagogic Practice in Global Contact Zones}

The analysis now turns to constructing portraits of pedagogic practice (Lightfoot, 1983) from the interview accounts of three teachers, focussing on this issue of topic selection. Data extracts from each teacher's interview that address pedagogic dilemmas of managing cultural sensibilities in the classroom are analysed to derive themes and contradictions with which to characterise each teacher's position and professional responses. The three pedagogic positions have been selected to offer a range of strategies: from the first teacher's studied avoidance of any hint of cultural offence; through the second teacher's attempts to find some compromise solution to cultural tensions; to the third teacher's confronting challenge to cultural sensibilities. In constructing these portraits of pedagogic practice our data analyses focus on the following key analytic questions:

- What moral dilemmas do the teachers recount? How do they attempt to manage these dilemmas in the globalized pedagogic contact zones of higher education institutions?

- Does the management of these dilemmas lead to pedagogic contradictions?

- What attributes of professional conduct are associated with handling such dilemmas and contradictions?

- What theories of globalization, cultural identity and academic preparation inform these accounts?

Of the three teachers profiled in detail in this paper, Teacher A had postgraduate qualifications and taught in a preparatory program for prospective Master of Business Administration (MBA) students. He described their English language proficiency as less than the required entrance levels of IELTS 6 or 6.5. The observed lessons covered essay structure, preparing and presenting oral presentations. Teacher $\mathrm{B}$ had a Masters in Education qualification, and seven years experience teaching in school and tertiary settings in Australia. She described her observed class in the EAP program as of 'intermediate' proficiency. The observed set of lessons focussed on the structure and delivery of seminar presentations, culminating in assessable student seminars, and some work on expressing cause/effect and generalizations. Teacher $\mathrm{C}$ had postgraduate qualifications and extensive experience teaching in tertiary settings in many different countries. She was one of the few teachers employed permanently. Her observed EAP class had 15 students, aged between 19 and 44, whose proficiency level was approximately an average of 5.5 on the IELTS scale. The EAP program prepared students for university in Australia, and 'to meet entrance requirements' by in-house assessments. The observed lessons dealt with style and structure in written assignments.

While the classes taught by these three teachers varied somewhat, the moral issues that they had to manage were similar. All of these teachers talked about having to manage cultural sensitivities while at the same time ensuring that students met the English language proficiency and academic skills requirements for entry into mainstream university courses.

The following three portraits provide more detailed accounts of the dilemmas produced between the teachers' acknowledgement of culturally sensitive topics and their desire for student participative behaviours associated with pedagogy roles in the Western university, and with communicative models of second language pedagogy.

\section{Pedagogic Strategy 1: Studied avoidance of controversial topics}

In response to a research question about Asian culture and learning styles, Teacher A suggested that there is an 'Asian-type' student who has been socialized in a culture of 'deference and reverence to ... older people'. This however did not imply for him that Asian students were 'quiet, passive learners'. Rather, what was significant was that they lacked experience in Western style genre, and thus did not have the skills to complete a literature review, academic essay or reflective journal. Moreover, he suggested that 'Asian-type' students found it difficult to understand assignment questions because of a 'lack of acute understanding of the task words - describe, explain, compare, contrast'. Throughout the interview, Teacher A evoked his professional knowledge or expertise in linguistics to explain or account for the design and enactment of classroom lessons. In the selection of data that follows, the interviewer asks Teacher A about his marked choice of the "cats and dogs" topic for an observed 
group discussion exercise wherein students were to collaboratively plan the structure for a compare/contrast expository text.

\section{Extract 1:}

R: Now the choice of topic for the task you set up was to compare "cats and dogs"... Do you want to talk about your reasons for choosing that topic?

Teacher A: Well, with Thai students it's okay because they don't dislike dogs. With Chinese I run into problems because a lot of them think that a dog is a dirty animal. It's not something that you have around the house, such as we have in Australia. But cats and dogs, I think, are probably simplistic which is why I choose them. They're easy to understand. Almost everybody knows what a cat and a dog is. When we do compare and contrast essays I don't want to encumber the exercise by dealing with intellectual ideas that are not understood. So I take really simple ideas but I keep on trying to reinforce that academic assignments are on topics a lot more complex than cats and dogs but the same thing applies... So once we have a good foundation of comparing any two simplistic things then we can get into the heavier material with greater number of paragraphs and more complex compound sentences but the structure is still the same.

(2 turns omitted)

R: ... What other potential topics do you see as sensitive for this group?

Teacher A: Oh, well, I actually looked at it the other way. I tried to think of things that wouldn't be sensitive... Things that are universal. If I don't use "cats and dogs" I also use "rainbows"... Because I try my best to keep any kind of politically sensitive material out of the class. I just pick things that I'm happy with, and that are common things so we don't stumble over what do we mean by "rainbow".

R: So with this last semester with the events of New York (September 11, 2001) has that been discussed in the classes at all?

Teacher A: No. No. I can hear myself saying once in a while when we come to topic " $X$ " that we're not looking at this from the "political" viewpoint. We're looking at it from a "language" viewpoint. ... In terms of the New York event - no it never quite came up as such. And, in fact, I do have an Arabic man in that class. No, I just stay away... I don't think it's necessary to bring it in for what I'm doing. ... Not that it shouldn't be spoken about or should be avoided, but in the material that I'm going over with them it's not appropriate. It's not necessary. ... I guess I also don't want to make any of the students feel responsible for their government's action. ... Why make them feel uncomfortable by bringing up topics that really aren't germane to linguistics? They might be central to marketing or other subjects, but not linguistics.

Teacher A offered the most extreme account of a pedagogic position among the nine teachers where potentially sensitive or controversial topics were consciously averted in the interests of protecting perceived cultural sensibilities. Teacher A's pointed avoidance of substantive controversy in the classroom sat uncomfortably with his account of the importance of eliciting student discussion in Foundation programs:

\section{Extract 2:}

R: And your reasoning behind obliging them to ask ... a number of questions through the presentation?

Teacher A: Well, because I feel that here at the university when they take part in group activities it's something that a lot of them don't want to do. ... And I'm being really onerous on them by insisting that they participate because part of the whole tutorial thing is allowing someone to understand what you're thinking about. ... So I try to suggest to them that this involvement, the give and the take, the turn-taking is part of what we do. And I think part of our educational process is more argumentative, in the true sense of argument not tantrum.... It's more argumentative than a lot of other cultures, where they accept someone's discretion and that's it. Whereas, here, we go for the chink in the armour and we say, "Well, now wait a minute, mate. What about that time? Why didn't it work then?"... And that's argumentative: the pros and cons. I try not to change them as people but I try to expose them to the fact that our situations are going to be a little different.

For Teacher A, cultural sensitivities were to be respected by including only topics that were: (1) simplistic and not encumbered with complex intellectual ideas; and (2) likely to have universal appeal 
to the diverse cohort of students. He also justified this topic choice in terms of his reluctance to engender unnecessary student emotion, as well as run the risk of forcing students to wear collective versions of their culture/history. Teacher A also suggested that the subject of linguistics unlike other subjects such as marketing could be demarcated by strong boundaries that excluded potentially controversial or sensitive topics. This choice of topics however, may not generate student discussion and participation in lessons. Consequently, Teacher A staged pedagogic exercises to encourage students to learn how to act as 'Western students' in tutorial or seminar sessions. He provided two explanations for taking up this pedagogic position. First, he suggested that Asian international students need to develop communicative skills in the argumentative style of Western academic work. Second, he proposed that talk makes visible student thinking processes, and therefore is a crucial teacher evaluative resource. Such staged exercises in 'doing seminar presentations' however did not engage students in the substantive content of the seminar presentation. The teaching of form was given more importance than engagement with content (see Doherty \& Singh, 2002).

Of particular interest, is an important disclaimer, or rider, that Teacher A placed on his pedagogic position: I try not to change them as people but I try to expose them to the fact that our situations are going to be a little different. Through this construction of the teaching/learning process, Teacher A attempted to distance himself from a potential charge of constituting neo-colonial pedagogic relations by forcibly socialising students into new pedagogic identities, that is, of producing some cultural homogenisation. His pedagogic position was substantiated through recourse to a pedagogy of choice, that is, offering students alternative knowledge/models. This careful distinction is present in other teachers' talk, and perhaps is their way of dealing with the difficult moral ground they are on - where the provision of Western knowledge and English language instruction is always fraught with a potential charge of neo-colonialism.

\section{Pedagogic Strategy 2: Compromising or Compromised Pedagogy}

In contrast to Teacher A's careful attempts to avoid cultural controversy while at the same time imparting the linguistic skills and techniques of English communicative competence, Teacher B offered a very different account of how cultural frames can intersect and work together in these contact zone pedagogic spaces. In this extract, Teacher B starts to talk about her misgivings and dilemmas over the content and structure of the EAP curricula. Specifically, her concerns are about the lack of an international focus in the EAP program, and therefore her own inability to meet the educational needs of the diverse student cohort. This extract of data is generated in response to an interview question about how the teacher's knowledge of the students' background informs her planning.

\section{Extract 3:}

Teacher B: ... I think we don't internationalise the curriculum. ... We tend - I'm saying 'we', I should say ' $I$ ', but it seems to me that a lot of us are doing the same thing. I suppose I shouldn't make assumptions about that. But because the course is so prescribed and when you talk to a lot ...of the other teachers we seem to do a lot of the same things. ...The students come here and it's kind of like we impose all of the teaching methodology that we have.... If you give these students [Asian international students] too many choices they're like, "You're the teacher. You do it." ... I think there are benefits from collaborative learning, ... but these guys are not convinced of them. So what's the point of shoving something down their neck if they are not convinced it's going to work anyway? So I try not to give them as many choices as I would a class of Australian students. ... They [Asian international students] are used to sitting in a classroom - and this is a generalisation - sitting in a classroom, taking notes, and then learning those notes, and then regurgitating them for an exam. So they'll often even articulate that they think it's not fair that they come over here and they're expected to learn a lot in a really short period of time. They are expected to learn about critical thinking and evaluation and all the things that we put value into. Often this knowledge is completely alien to these students. They're like, "Why are we doing this?" ... And I think that ... if a teacher has any sensitivity towards the students, then he/she should try and balance the program out a bit. We should not just impose our Western, Australian methodology on them. Although I think I probably do it more than I think I do. ... But I try to be aware of some of the things that might make them feel uncomfortable ... I think I'm more directive with these students, more input, more speaking and whatever else I do, than I do with Australian students when I teach them. ... I hope I'm not being condescending or patronising. I think I'm doing it because 
sometimes when the students get out of their comfort zone they can't or ... they don't operate to the best of their abilities.

According to Teacher B, the EAP curriculum is about Western learning strategies and demeanours, a set of practices she described as 'completely alien' to the students. Moreover, the EAP curriculum is characterised as an 'imposing' pedagogy, taking the students 'out of their comfort zone'. Teacher B expresses a degree of discomfort with the imposition of a prescribed curriculum and teaching methods, and sees it as incongruent with the policy discourse of 'internationalisation'. At the same time, Teacher B does not cast herself as having any control over the curriculum, with which she seems to have some issues. Her account poses this quandary, which she then partially resolves with reference to the pedagogical compromises she makes to accommodate the students, suggesting a reflexive, mutual negotiation and compromise in 'how' these classes are done.

In the following extract, Teacher B elaborates on her concept of internationalising the curriculum as a hybridizing exercise in mutual enrichment:

\section{Extract 4:}

$\boldsymbol{R}$ : So then what exactly would you mean by 'internationalising' in relation to what you have just said? ... As opposed to assimilation.

Teacher B: So what about then taking in using some of the learning styles that they have. Like, instead of rejecting rote learning as being something that's not valuable why not somehow incorporate aspects of everything. All the different learning styles. Like, you think about it if the Chinese, for example, who tend to value rote learning being able to regurgitate thousands and thousands and thousands of facts. I always sort of think we kind of poo-poo that here but you look at their culture. Their culture has been around for how long? That's got to have worked for them in whatever way it worked. So how can we say that that is not of equal value to ours? So then how do we incorporate those aspects of their culture together and make something? I don't know.

$\boldsymbol{R}$ : So that's what you mean by internationalising?

Teacher B: ... I don't know. Internationalising is really a difficult concept to pin down I think but it's, I think it's like making knowledge and education accessible to everybody without them having to change everything about themselves. Like becoming little Australians or new Australians to be successful here, isn't it?

This vision of some optimal cultural hybridity is denied however by the institutional setting that fails to embrace internationalisation of the curriculum and pedagogy:

\section{Extract 5:}

Teacher B: What is my role? I guess my role is to show them what they need to know to assimilate. I don't limit what I say or change the process because the end result is that they will go into university courses which have not been internationalised.

On the matter of culturally sensitive topics, Teacher B is less ambivalent, less accommodating and more confrontational than her position on internationalisation may suggest, though it marries with her more robust construction of culture. Put simply, she takes up an acculturating or cultural homogenization pedagogical stance suggesting the importance of providing students with the resources needed to succeed in the mainstream Western university context:

\section{Extract 6:}

Teacher B: if there was something in the content that was really vilifying a religious group or a cultural group then, I probably, I don't know if I'd no, I'd actually no, I don't think I would cut it out because you know, you think about uni here. We listen to a lot of opposing views, don't we? We may not agree with them but part of our culture here is that you listen and then you evaluate. You don't attack before you have listened. So if there was something like that maybe I would play it but then we'd talk about it later. Yeah. So, no there's not really anything.

In summary, Teacher B's pedagogical strategies are informed by a robust, generative notion of cultural processes. She talks about the self-governing community of common practice amongst the EAP teachers that does not overtly challenge or contest the prescribed curriculum and pedagogic structures. At the same time, she acknowledges that students do exercise some control over the curricular content 
through their resistance and complaints. She talks about a distinction between the beginning and later parts of the course, in terms of accommodating cultural differences. The implication is that as the course progresses, less allowance is made for students to adhere to different teacher/student models, and that they are shaped towards the normative Western model by the end of the program, which could be interpreted as a homogenization process. While she can articulate a vision of what internationalisation might entail, she finds her conditions of employment and the institutional setting justify an acculturating or cultural homogenization pedagogical stance that prepares students for, by her account, a starker more biased reality.

\section{Pedagogical Strategy 3: Deliberate Provocation to Generate Classroom Discussion}

Where Teacher A and Teacher B considered the cultural sensibilities of their students and designed their pedagogy around these to varying degrees, Teacher $\mathrm{C}$ is quite uncompromising in her pedagogical strategy. Teacher $\mathrm{C}$ expressed no reservations about the strongly framed curriculum or pedagogy of the EAP or Foundation Studies programs. Rather she suggested that the explicit objective of the courses was to 'acclimatise' students to the cultures of learning in Australian universities. This meant that students needed to become familiar with both the content and styles of teacher-student relations in Australian universities.

\section{Extract 7:}

$\boldsymbol{R}:$ Do you think in terms of an Asian culture?

Teacher C: ... I think you would get a very different answer had you talked to me when I was teaching, say in Bangladesh or in Saudi Arabia or in Nigeria, which are the three Muslim areas I have lived in where I was, I'm sure, careful to some extent, of what I said so as not to offend people. But here, not that I'm trying to offend people, but I feel we are acclimatising these students to being in Australia. And rather than not say something because I might offend them, I will say something and then say that I realise that some people may not see this in exactly the same way because they might be Muslim or blah, blah, blah but that's the way it is in Australia. And I feel that that's important that we don't avoid these things because if I were in their country I would be doing that. But here I don't. And I feel we're training them. You know most of them are going to be here for another two, three years and I think part of what we're doing is getting them used to the Australian scene. If there's somebody in the class who I know might be offended, I would say, "I know that you think differently about this." Or, "I don't want to offend you by saying this, but...". So I'll let them know that I'm aware of it but I don't tread around and think I'm in an Asian culture. I'm not. I'm in an Australian culture. In Bangladesh that's very different. I am in their country and I am doing things their way.

Teacher C's pedagogical position of cultural homogenization was crystal clear and unequivocal. The students had travelled to Australia to acquire an Australian qualification. Thus, there were would be no or few changes made to the curriculum or teaching strategies. Rather, it was the student's task to adapt or acclimatise to the knowledge in the curriculum packages and in the classroom lessons. By her account, Teacher $\mathrm{C}$ acted in what she perceived to be students' long term interests, and her abrupt staging strategy aimed to bring these students into what she constructed as the Australian model of teacher-student relationship as quickly as possible, in contrast to the gradual staging of Teacher B, or pluralist respect of Teacher A. In other words, Teacher $C$ alluded to the importance of ensuring that international students acquired the same knowledge as their Australian counterparts. There would be no 'dumbing down' or 'watering down' of the knowledge for this cohort of students.

\section{Comparing and Contrasting Strategies for Managing Pedagogic Dilemmas}

Where the institution's entrance pathways and the curricula construct the preparatory phase as a simple, benign exercise in cultural briefing, these three teachers' accounts suggest that the undercurrents of cultural sensibilities make this a more fraught and hazardous process than it is acknowledged to be by the institution, and that teachers have to steer their own courses in the absence of such institutional insight. Under their conditions of casual contracts, prescribed curricula and high contact hours, these teachers are negotiating a difficult space constituted between their professional ethic of cultural respect, and the 'acculturating' imperative of the curricular design. The tension between these two imperatives is managed in different ways by the individual teachers in the space of freedom offered by the classroom, though their accounts suggest that this is an ongoing and escalating struggle for them. To 
suggest that there is a simple one-size-fits-all way to resolve these tensions would be to deny: the complexity of any university as an institution and its disciplinary cultures; the shifting nature of markets in international education; the relative status of the EAP/preparatory teacher; and the relative customer power of the international student body as Australian universities become more reliant on their income. In the following commentary, we problematize each of the teachers' patterns of resolution to the dilemmas they encounter, in order to acknowledge and open the debate about how teachers can work in this ambivalent and shifting moral space. This debate is necessary given the accelerating pace and disjunctural nature of global cultural flows, that is, flows of ideas, images, people and finances. The cultural politics of globalized education will become increasingly uncertain, complicated and problematic.

Teacher A chose an 'effaced' pedagogy and carefully sanitised the curriculum stripping it of intellectual engagement, so that the linguistic aspects of the target genre could be foregrounded and performed in a template fashion. The degree to which he reportedly avoided what he considered potential controversy begs the question of whether assumptions on what constituted the controversial were ever tested. In other words, Teacher A's imaginary constructions of controversial, as well as culturally sensitive or respectful topics, constituted what counted as curricular content in the pedagogic contact zone of the Foundation business communications course (see Appadurai, 1996). For this teacher the globalized pedagogic contact zone was a minefield of cultural sensitivities, from which it was his professional duty to protect the students. In teaching students about this contact zone, Teacher A constructed cultures and cultural identities as discrete, internally coherent, stable yet fragile. Alert to possibilities of cultural homogenisation, he offered the international students a syncretic, relativist choice between cultural frames as a way of managing the dilemma inherent in the 'conversion kit' curriculum.

Teacher B chose a 'saving face' pedagogy to manage the moral quandary arising from the perceived collision of culturally inscribed teaching/learning models. The international student is constructed as a passive, reproductive, dependent learner, who avoids interaction, and requires more overt instruction. On the other hand, Teacher B talks about student protest and resistance, where ironically students assert their right to be relatively passive. Thus two polarised learner/teacher models are evident in Teacher B's account - one is the Australian/Western model of interactive teacher/learner relationship, the other is a passive student/directive teacher model attributed to the students. She portrays these two models as operating in conflict, with some pedagogical negotiation between them, for example her accommodation of students' preferences by fulfilling their expectations of teacherly conduct. She uses the term 'assimilate' without any qualification, but by her account, washes her hand of any attendant moral stain associated with it. The blame lies with the unforgiving institutional setting which constrains her pedagogical possibilities of doing transcultural or hybridizing work in globalized contact zones.

Teacher B's account presents internal inconsistencies and dilemmas. As a teacher, she is not in control of the curriculum, its pacing, or the policy environment and by her account, neither she nor her students are entirely comfortable with the values and intentions inscribed in the curriculum. Elsewhere in her interview, she depicts herself as distanced from any decision making power: 'I'm no one in this.' She thus constructs herself as a passive subject of institutional power relations, rather than as an active agent responsible for choosing curricular content and pedagogic strategies. Her account of the process students undergo in this program is presented as the imposition of another homogenizing cultural frame, and of resulting student resistance. Cultures in this teacher's account operate in conflict where they coexist and exert pressure on each other - a more robust, dynamic, overlapping and interactive construction of culture than the discrete fragility expressed by Teacher A. She invokes the term 'internationalisation' as an alternative to cultural imposition, and by implication is imagining a possibility of mutual accommodation, and of reconciling multiple frames to co-exist, and enrich each other. Her articulated position on internationalisation thus sits more comfortably with a hybridizing rather than a homogenising notion of pedagogic work in globalized contact zones or spaces. At the same time, however, she does not view the considerable adjustments she reports making to accommodate student preferences as ‘internationalization' bestowed by the institution.

Teacher $\mathbf{C}$ chose a pointed 'in your face' pedagogy to deal with the moral dilemmas associated with teaching in the global university contact zone. For Teacher $\mathrm{C}$, culture is local and situated, that is, place dictates the appropriate cultural script. Her heightened sense of culture as located, rigidly bound social practice meant that her professional judgements on what to include or exclude changed according to where she was teaching. Offence was to be avoided when elsewhere, but was pointedly not to be 
avoided in the Australian-based preparatory course: that's important that we don't avoid these things. Any sense of dilemma is unapologetically resolved by this device. She uses the term 'acclimatise' to refer to this notion of situational adaptation, which distances her from the 'assimilation' discourse Teacher B slipped into. The contradiction inherent in this pedagogic strategy is the fact that this well travelled teacher can retain such an unproblematically homogeneous, located notion of culture, despite her extensive experience in, and contribution to, the globalized/globalizing educational circuits and flows that are increasingly blurring or breaching such spatial boundaries. This professional sense of context sensitivity will produce very different educational outcomes in different locations.

Our analyses have depicted three positions on a continuum: one of 'effaced' avoidance at one extreme; one of pointed 'in your face' confrontation at the other extreme; and a middle ground, 'saving face' for both teacher and students. We do not mean to imply that each teacher struck rigidly to one pedagogic approach. Indeed, our analyses of the video-taped lessons of each teacher showed movement across the range of pedagogic strategies described in the preceding section. In general, our analyses concur with observations made by Allan Luke (2002, p.52) who suggested that many EAP teachers remain 'dedicated and committed educators' with 'political commitments' and concern for the communities within which they work. In these new globalized and globalizing times, EAP teachers' political commitments are often 'expressed as a need to be "culturally sensitive”, culturally appropriate”, to avoid either the aculturalism of technocratic education or the cultural imperialism of Western education' (Luke, 2002: 52). At the same time, we want to suggest that while most teachers expressed a need to be culturally sensitive or culturally appropriate, the pedagogic strategies articulated in their talk and enacted in classroom practices ranged from acultural technocratic, bald cultural assimilationist, and more tempered compromising approaches. 


\section{Discussion}

Teachers in these preparatory courses constitute the front-line in educational contact zones, and they wear risks and moral dilemmas on behalf of their institutions and end-users. They are the ones that have to live through the awkward moments of discomfort, offence or distrust with students when sensitive topics are broached, and sensitivities are breached. The teachers' professional discourses for making sense in these matters, as sampled above, constructed culture in different ways - as the stable, reproductive 'primordial' ethnic category (Appadurai, 1996), as discretely located social practices, or as established bodies of social practice on collision courses. Significantly, none of the teachers engaged with issues or discourses of globalization, hybridity or cosmopolitan identities premised on some global cultural form. Their commonsensical constructions and received wisdom about mutually exclusive cultures, and in particular cultural learning styles, that inform the design of these preparatory curricula, have in effect created the ambivalent spaces and moral dilemmas for them.

Indeed, a number of researchers have now argued that the 'received view' of culture dominates practitioner work in the TESOL field (see Atkinson 1999a, 1999b; Pennycook 1999a, 1995; Holliday, 2001). For example, Atkinson (1999b, p.625) has argued that while culture is 'implicitly and explicitly' involved in every aspect of TESOL practice, this ubiquity fosters an unexamined, taken-forgranted, or common sense construction of the term. Culture or cultures are typically defined in the 'received view' as 'geographically (and quite often nationally) distinct entities, as relatively unchanging and homogeneous, and as all-encompassing systems of rules or norms that substantially determine personal behaviour' (Atkinson, 1999b, p.626). This version of culture, we suggest, can not adequately serve a profession whose work is so intimately involved in the cultural intersections of the global contact zone.

In the first section of this paper we offered a different, relational construction of culture as resources and imagination produced, negotiated and appropriated through contact with difference. Higher education was explored as a contact zone where, cultural identities struggle over their representation in a process of mutual entanglement. Thus, the design of preparatory curriculum for this contact zone demonstrates not only how the Western institution understands and represents its international student body, but also how the institution imagines and projects its own identity even as its constituency is in the process of changing. The paper then outlined the debate surrounding cultural processes under conditions of globalization. In particular the distinction was made between competing predictions of inevitable homogenization, polarization and hybridity. Rather than subscribe to a particular position, we suggest that the TESOL profession treat these as competing potentials that could eventuate in the micro setting of the preparatory classroom.

To assist in this reconceptualization of cultural processes and potentials, Appadurai (1996) suggests that we avoid the noun 'culture' as too problematic now, with its inherent logic of entities that can be held apart. He suggests that we retain its adjectival form, 'cultural' which he suggests is more relevant and useful to characterise the flow of deterritorialised resources available to people with which to imagine and assemble their identities amidst alternatives. In this light, to construct the international student's country of residence and Australia as mutually exclusive cultures (noun) isolated from each other is to overlook the landscapes or cultural (adjective) flows they share under current conditions of globalization (ethnoscapes, technoscapes, finanscapes, mediascapes and ideoscapes), and to deny the contact zone both teachers and students occupy. To deliver programs that construct idealised narratives of a pure Western academic tradition is to erase considerations of changing circumstances, politics and economies in Australian universities, and also to deny the substantial international student body any transformative power. Curricula that promote such an idealised narrative effectively construct a textual truth that elides the complexities and shifting parameters of the Western 'global' university. To move professional debate and practices beyond the sticky moral dimensions displayed above, disciplinary notions of cultural difference need to be revisited and renovated to reflect the impact of globalization in the trajectories of the university, the teachers, and the students.

The danger of the theoretical concept of globalization, however, is that it presents as a monolithic fait accompli beyond the agency or purview of any individual or organisation, which makes it possible to overlook one's own professional contributions to, and involvement in its progress. Appadurai's disaggregation of the '-scapes' help to disassemble and analyse constituent global flows, so we can understand where, how or what we are contributing. Shome and Hegde (2002, p.217) remind us that globalization is a 'process and a phenomenon ... that has to be actively implemented, reproduced, 
serviced and financed ... and relies for its functioning on several overlapping structures and relations, from the local, to the national, to the global.' The EAP and Foundation teacher is not 'no one in this', to borrow Teacher B's phrase, but rather a very necessary part of the global machinery, lubricating the local points of contact.

There have been moves in the TESOL profession to unsettle the commonsensical construction of culture in terms of disputing the characterization of certain cultural types. In particular, the construction of an Asian learner archetype has been challenged (Benesch, 2001; Biggs, 1997; Chalmers \& Volet; 1997). Some theorists have explored the relations between dominant and 'Other' groups. Spack (1997) warns about the limitations of any essentializing cultural labels, and the need 'to examine our own identities' (p.773). Kubota (1999, 2001) deconstructs the powerful script of East/West dichotomy as a colonial discourse that perpetuates vested interests. Nichols (2003) explores the tension between opportunistically positive and negative constructions of the international student in Australian universities. These writers provoke reflection on who is invoking culture on whose behalf and to what end. There have also been suggestions on how to design a new, more democractic, cultural politics in transcultural pedagogies (Giroux, 1992; Canagarajah, 1997; Badley 2000; Holliday 2001).

However, the critical pedagogy frequently framed as the solution (Benesch, 2001; Kubota, 1999) still casts the teacher as some transcendant agent outside the cultural influences of the pedagogical contact zone, who can orchestrate the encounter and protect students from the imagined deleterious effects of cultural contact. But are these strategies a tad paternalistic in the way they construct the teacher as protector of the Other's cultural identity? Do they in fact work to 'fix the Other' in a form of indulgent, protective Orientalism (Pennycook, 1999b, p. 17)?

We suggest that TESOL professionals need to renovate the 'discoursal baggage' (Holliday 2001, p.124) they bring to their pedagogic practice, and to embrace new constructions that unsettle previous assumptions and truths. Moreover, we propose that globalization theory offers a new vocabulary for an emerging and pressing reality that cannot be ignored. EAP, ESL and Foundations studies practitioners need to engage with new theorizations of culture, and cultural processes of globalization, and write themselves into these scripts as both active agents and subjects of the transculturation effect as much as the students sharing the contact zone (see also Zamel, 1997). Polarized cultural caricatures of a 'pure' West and an 'unsullied' East are no longer tenable as heuristic devices in this discourse, while cultural intersection, appropriation and hybridity may not be such a morally repugnant outcome (Ang, 2001). Students seeking the cultural capital of global cultural forms and practices are not victims to be protected, but rather are proactive agents purposefully and advantageously imagining and positioning themselves in global flows, just as teachers and higher education institutions are also engaging in the global exchange of ideas and finance to their advantage. The English language and the textual practices of business and higher education no longer belong to an exclusive Western 'us', but are tools and practices engaged with and shaped by a global 'us'. Undoubtedly, some are more advantaged than others in these global flows, but any tactic of protective cocooning of the 'Other', as demonstrated by Teacher A's effaced pedagogy, needs to be questioned.

Though reluctant to suggest some solution in these 'postmethod' times (Canagarajah 2002), we suggest that curricula in the contact zone can exploit and explore the many points of intersection or confluence, and legitimise hybridised identities in a 'facing up' pedagogy. This pedagogy would recognise that English and the circuits of Western higher education are also part of Asian students' worlds and need not be packaged with some localised orthodoxy. On the particular matter of resourcing the EAP classroom explored in the empirical section of this paper, English language publications produced in non-West settings offer a legitimate source of texts for the contact zone classroom. International issues framed through multiple perspectives and diverse textual constructions, not just domestic versions thereof, can serve to stimulate the communicative environment sought for language learning. Such texts would work to de-centre the teacher's traditional authority as cultural informant, and the usual construction of international student as naïve inductee. With access to the Internet, no teacher need restrict themselves to commodified resources with their attendant risk of patronising ideologies drawn from developmental discourses. Such decentring of textual authority would be preferred to goading students through 'in your face’ pedagogy which risks repelling them into polarized positions.

In addition, the growing policy discourse of internationalization may give the profession a valuable window of opportunity to turn informer and take the role of provocateur within their institutions. By reflecting on how they themselves have been effected by the contact zone, the TESOL profession has 
much to share with the Western 'global' university as they 'face up' to their new demographic constitution.

This rosy agenda does not get rid of all moral dimensions. As we have outlined in the first section, globalisation is understood to have multiple competing potentials, being cultural homogenisation or reactive polarization, as well as generative hybridization. EAP and Foundation Studies programs can still work to pull students into homogenizing scripts, or repel them into antagonistic opposition, and as teachers we won't necessarily be in control of the fluid and fluctuating events that contribute to such outcomes: ' $\ldots$ where there is risk there is opportunity. Individuals are not the dupes of overpowering social structures and events, but active, reflective agents in the ongoing construction of social reality' (Cameron and Block, 2002, p.4). If we can embrace and value expressions of hybridity, that is the sharing of cultural resources in indigenised/localised form, as valid and valued expressions of cultural identity for current times, then we may be able to steer some middle path between McWorld and a clash of civilizations.

\section{ACKNOWLEDGEMENT}

This is a significantly revised version of a paper included in the AARE Conference Proceedings (2002, December), Brisbane, Australia. The study reported in this paper is part of a larger project funded by the Australian Research Council.

1 The term international student came into wide usage in Australian official higher education policies during the 1990s, and was used to distinguish full-fee paying overseas students from domestic/local students.

2 Top ten countries (Foreign or International Students at Australian universities, online or at offshore campuses). Singapore 24,400; Hong Kong 24,300; Malaysia 23,600; China 21,400; Indonesia 10,000; India 8,300; US 7,800; Thailand 4,700; Taiwan 3,700; Norway 3,600 (Noonan, 2003, p.6)

${ }^{3}$ Following Appadurai (1996, p.13) we use the adjectival term cultural to stress the 'contextual, heuristic, and comparative dimensions' that orient us to 'the idea of culture as difference, especially as difference in the realm of group identity'.

${ }^{4}$ International education has been described variously as 'Australia's seventh largest export earner gleaning $\$ 4.2$ billion in foreign exchange earnings annually’ (Noonan 2003, p. 6); a ‘5.2 billion education export industry' ( Illing 2003, p. 19); and an 'overseas student market worth $\$ 5.2$ billion to Australia' (Contractor 2003, p. 3).

${ }^{5}$ Colonization refers to the 'whole process of expansion, exploration, conquest, ... and imperial hegemonization which constituted the 'outer face', the constitutive mode, of European and then Western capitalist modernity after 1492' (Hall 1996, p.249). Some theorists suggest that colonization processes were earlier versions of current globalization processes.

${ }^{6}$ A quick Yahoo web search for the phrase culture shock elicited 663,000 sites. These sites were produced by: universities, Education Departments, Foreign Affairs Departments, travel agents, business organizations, private English language schools, expatriate teacher organizations, and international student groups. Many of these sites draw heavily on Oberg's (1960 cited in Bodycott \& Crew 2001, p.4) six negative characteristics of culture shock:

1. Strain or stress relating to psychological adaptation;

2. A sense of loss or deprivation resulting from the removal of friends, status, role, and personal possessions;

3. Fear of rejection by or rejection of the new culture;

4. Confusion in role definition, expectations, feelings and self-identity;

5. Unexpected anxiety, disgust or indignation regarding cultural difference; and

6. Feelings of helplessness.

Participants experiencing culture shock were found often to experience confusion, frustration and depression. 


\footnotetext{
${ }^{7}$ Knight and de Wit (1995, p. 16) provide a widely cited definition of internationalisation as 'the complex of processes whose combined effect, whether planned or not, is to enhance the international dimension of the experience of higher education in universities and similar educational institutions'. This definition is frequently cited in policy documents in the Australian higher education sector. For example, the Australian Vice Chancellors’ Committee (AV-CC) (1999, p.21) suggests that Australian universities are internationalising curriculum through the introduction of:

- $\quad$ additional international content into courses

- $\quad$ comparative and cross-cultural approaches

- language and area studies

- $\quad$ interdisciplinary programs covering more than one country

- joint degree courses involving a professional course linked to an international studies/language course

- $\quad$ courses taught in part overseas or involving a study abroad component

- a placement in an overseas institution or a study abroad component

- $\quad$ courses using visiting academics from overseas
}

${ }^{8}$ Appadurai (1996, p. 41) argues: 'that the central paradox of ethnic politics in today's world is that the primordia (whether of language or skin color or neighbourhood or kinship) have become globalized. ... such primordia are often the product of invented traditions ... or retrospective affiliations.'

9 'Ambivalence refers to affective states in which intrinsically contradictory or mutually exclusive desires or ideas are each invested with intense emotional energy. Although one cannot have both simultaneously, one cannot abandon either of them' (Flax cited in Ang, 1996, p. 44).

\section{${ }^{10}$ Teacher interview questions \\ First stage - generic questions:}

1. How do you find out about the educational/language needs of your student clientele? How does this inform your planning?

2. What are the most common learning strategies used by your students? Do you notice any significant changes in the way the students are learning during the course? What do you see as your role in this process? (Examples?)

3. What do you want your students to be able to do by the end of the course? How do you teach this? (what do you see as your role?). Is this familiar to/different from what they are used to?

4. There are now a variety of Englishes (Australian, British, American, Singaporean, Indian etc.) Do you work with these different types of English in your lessons? (If yes, how?)

5. Do you think in terms of an "Asian” culture? How does this affect your interactions with students?

6. What do you think students want from their educational experience here in Australia?

7. Do you think students experience any tensions between their own culture and what they experience here? How do you manage these tensions?

\section{Second stage - stimulated recall of videotaped teaching practice:}

1. We're interested in what was going on there and what were your intentions.

2. Would you like to talk about why you chose that as an activity and what you hope the students would get out of it?

${ }^{11}$ Fictional names are used to protect the confidentiality of participants. Interview data has been edited to ensure that meanings conveyed in oral interview accounts are represented accurately in the written form.

12 This data constituted part of a larger study that included: student interviews, curriculum materials, brochures and audio or video-recordings of classroom lessons. Four teachers were videotaped teaching in the intensive EAP programs, and five teachers were videotaped teaching in Foundation programs that provide alternative university entrance. A total of 4 or 5 classroom lessons were video-taped for each teacher. 
${ }^{13}$ The observed classes were coded and cross checked by two research assistants, firstly by phase of lesson following Lemke's (1990) activity types. These specialised international practices include triadic dialogue, teacher student debate, student questioning, teacher monologue, external text dialogue, teacher-student duolog, seatwork, groupwork, board-work, true dialogue, cross discussion, media presentation, teacher summary, and testing. Markers for changes between specialised interactional practices were noted. The topics covered in terms of the content of the lesson were coded. Markers for shifts in topics were noted. Interactive trouble such as student disruptions, failures to respond to teacher question, and challenges to both the specialised interactional practices (regulative order) and the topics (instructional order) were coded at the level of the exchange and pedagogic move. 


\section{References:}

Ang, I. (1996). The Curse of the Smile. Feminist Review, 52(Spring), 36-49.

Ang, I. (2001) On Not Speaking Chinese: Living between Asia and the West. London: Routledge.

Appadurai, A. (1996). Modernity at Large. Cultural Dimensions of Globalization. Minneapolis, London: University of Minnesota Press.

Atkinson, D. (1999a). The author responds ... TESOL Quarterly, 33(4), 752-755.

Atkinson, D. (1999b). TESOL and Culture. TESOL Quarterly, 33(4), 625-654.

Australian Vice-Chancellors' Committee (AV-CC), (1999). Australian Universities. International Universities. Canberra: Department of Industry, Science and Resources.

Badley, G. (2000) Developing globally-competent university teachers. Innovations in Education and Training International. 37(3), 244-253.

Ballard, B., \& Clanchy, J. (1997). Teaching international students: a brief guide for lecturers and supervisors. Canberra: IDP Education Australia.

Benesch, S. (2001). Critical English for Academic Purposes: Theory, Politics, and Practice. Mahwah, NJ: Lawrence Erlbaum Associates.

Berlak, A., \& Berlak, H. (1981). Dilemmas of Schooling: Teaching and Social Change. London: Methuen.

Biggs, J. (1997). Teaching across and within cultures: The issue of international students. In R. Murray-Harvey and H. C. Silins (Eds.) Learning and teaching in higher education: Advancing International Perspectives. (pp. 1-22) Adelaide: Flinders University Press

Bizzell, P. (1994). 'Contact Zones' and English Studies. College English, 56, 163-169.

Block, D. \& Cameron, D. (Eds.) (2002). Introduction. In Globalization and Language Teaching. (pp. 110) London \& New York: Routledge.

Bodycott, P., \& Crew, V. (2001). Short Term English Language Immersion: Paradox; Culture Shock; Participant Adjustment. In P. Bodycott \& V. Crew (Eds.), Language and Cultural Immersion: Perspectives on short term study and residence abroad (pp. 1-9). Hong Kong: The Hong Kong Institute of Education.

Bourdieu, P. (1992). Language and Symbolic Power. Cambridge: Polity Press.

Burawoy, M. (2000). Reaching for the Global. In M. Burawoy, J. Blum, S. George, Z. Gille, T. Gowan, L. Haney, M. Klawiter, S. Lopez, S. O' Riain \& M. Thayer (Eds.), Global Ethnography. Forces, Connections, and Imaginations in a Postmodern World (pp. 1-40). Los Angeles: University of California Press.

Buzzelli, C., \& Johnston, B. (2002). The Moral Dimensions of Teaching. New York: RoutledgeFalmer. Cameron, D. (2002). Globalization and the teaching of 'communication skills'. In D. Block \& D. Cameron (Eds.) Globalization and Language Teaching. (pp. 67-82) London \& New York: Routledge. Canagarajah, A. (1997) Safe Houses in the Contact Zone: Coping Strategies of African-American Students in the Academy. College Composition and Communication, 48, 173-196.

Canagarajah, A. (1999) Resisting Linguistic Imperialism in English Teaching. Oxford: Oxford University Press.

Canagarajah, A. (1999) Resisting Linguistic Imperialism in English Teaching. Oxford: Oxford University Press.

Castells, M. (2000). End of Millennium (Second Edition ed.). Oxford: Blackwell Publishers.

Castells, M. (2000). The Rise of the Network Society. The Information Age. Economy, Society and Culture. Volume 1. (2nd ed.). Oxford: Blackwell

Castells, M. (1997). The Power of Identity. The Information Age. Economy, Society and Culture. Volume 2. Oxford: Blackwell Publishers.

Chalmers, D. \& Volet, S. (1997) Common misconceptions about students from South-East Asia studying in Australia. Higher Education Research and Development, 16(1), 87-99.

Clifford, J. (1997). Routes. Travel and Translation in the Late Twentieth Century. Cambridge, Massachusetts and London: Harvard University Press.

Contractor, A. (2003, August 6). Failing grade for uni's overseas courses. The Sydney Morning Herald, p. 3.

Department of Education, Science, and Training (DEST) (2003). Students 2002 (First Half Year): Selected Higher Education Statistics. Canberra: Commonwealth of Australia. http://dest.gov.au/highered/statistics/students/02/tables.htm Retrieved 18 March 2003 Doherty, C. (2001) Internationalisation under construction: curricula and pedagogy for international students. In P. Singh \& E. McWilliam (Eds.) Designing Educational Research: Theories, Methods and Practices (pp.13-30). Flaxton: Post Pressed. 
Doherty, C. \& Singh, P. (2002) Simulating Western pedagogy: A case study of educational programs for international students. In P. Ninnes \& L. Tamatea, (Ed.) Internationalizing Education in the AsiaPacific Region: Critical Reflections, Critical Times, Proceedings of the $30^{\text {th }}$ Annual Conference of the Australian and New Zealand Comparative and International Education Society, Armidale, 6-8 December 2002, pp. 73-92.

Giddens, A. (1990). The Consequences of Modernity. Cambridge: Polity Press.

Giddens, A., \& Pierson, C. (1998). Conversations with Anthony Giddens. Making Sense of Modernity. Stanford, California: Stanford University Press.

Giddens, A. (2000). Runaway World. How Globalization is Reshaping Our Lives. New York:

Routledge.

Giroux, H. (1992). Border Crossing: Cultural Workers and the Politics of Education. New York \& London: Routledge.

Hall, S. (1996). When was the 'post-colonial'? Thinking at the limit. In I. Chambers \& L. Curti (Eds.), The Post-Colonial Question (pp. 242-260). London: Routledge.

Hafernik, J., Messerschmitt, D., \& Vandrick, S. (2002). Ethical Issues for ESL Faculty: Social Justice in Practice. Mahwah, NJ: Lawrence Erlbaum.

Holliday, A. (2001). Finding Social Autonomy. In P. Bodycott \& V. Crew (Eds.), Language and Cultural Immersion: Perspectives on Short Term Study and Residence Abroad (pp. 123-132). Hong Kong: The Hong Kong Institute of Education.

Holton, R. (2000). Globalization's Cultural Consequences. The Annals of the American Academy, 570(July), 140-152.

Humfrey, C. (1999) Managing International Students. Buckingham: Open University Press.

Huntington, S. P. (1997). The Clash of Civilizations. Remaking of World Order. New York:

Touchstone.

Illing, D. (2003, August 8). Compromised by copying allegations. The Australian, p. 19.

Keith, M. (1988). Stimulated recall and teachers' thought processes: a critical review of the methodology and an alternative perspective.Unpublished manuscript, Louisville.

Kenway, J., \& Bullen, E. (2003). Self-Representations of International Women Postgraduate Students in the Global University 'Contact Zone'. Gender and Education,15(1),5-20.

Knight, J., \& de Wit, H. (1995). Strategies for internationalisation of higher education: historical and conceptual perspectives. In H. de Wit (Ed.), Strategies for internationalisation of higher education: $a$ comparative study of Australia, Canada, Europe and the United States of America. (pp. 5-32). Amsterdam: European Association for International Education (EAIE).

Kubota, R. (1999). Japanese culture constructed by discourses: implications for applied linguistics research and ELT. TESOL Quarterly, 33(1), 9-35.

Kubota, R. (2001). Discursive construction of the images of U.S. classrooms. TESOL Quarterly, 35(1), 9-38.

Lemke, J. (1990). Talking Science: Language, Learning and Values. Norwood, NJ: Ablex.

Levin, J. S. (2001). Globalizing the Community College. Strategies for Change in the Twenty-First Century. New York: Palgrave.

Lightfoot, S. L. (1983) The Good High School. Portraits of Character and Culture. New York: Basic Books Inc.

Luke, A. (2002). Curriculum, Ethics, Metanarrative: Teaching and Learning Beyond the Nation. Curriculum Perspectives. 22(1) pp. 49-55.

Luke, C. (2001). Globalization and Women in Academia. North/West. South/East. Mahwah, New Jersey: Lawrence Erlbaum Associates, Publishers.

Maslen, G. (2002, September 11-17). Asia Remains Our Largest Student Pool. Campus Review, p. 2.

McMeniman, M., Cumming, J., Wilson, J., Stevenson, J., \& Sim, C. (2000). Teacher Knowledge in Action. In Department of Education, Training and Youth Affairs (Ed.), The Impact of Educational Research (pp. 375-550). Canberra: Commonwealth of Australia.

McMurtrie, B. (2001) Foreign enrolments growth in the U.S., but so does competition from other nations. The Chronicle of Higher Education, 16, 45-47.

Melucci, A. (1997). Identity and difference in a globalized world. In T. Modood (Ed.), Debating Cultural Hybridity. Multi-cultural Identities and the Politics of Anti-Racism (pp. 58-69). London and New Jersey: Zed Books.

Nesdale, D., Simkin, K., Sang, D., Burke, B., Frager, S. (1995). International Students and Immigration. Canberra: AGPS.

Nichols, S. (2003) 'They just won't critique anything': the 'problem' of international students in the western academy. In J. Satterthwaite, E. Atkinson \& K. Gale (Eds.), Discourse, Power and Resistance: 
Challenging the Rhetoric of Contemporary Education (pp. 135-148). Stoke on Trent, UK \& Sterling, USA: Trentham Books.

Noonan, G. (2003, July 2). Overseas student numbers surge 15\%. The Sydney Morning Herald, p. 6.

Papastergiadis, N. (1997). Tracing Hybridity in Theory. In P. Werbner \& T. Modood (Eds.), Debating

Cultural Hybridity. Multi-Cultural Identities and the Politics of Anti-Racism (pp. 257-281). London \&

New Jersey: Zed Books.

Pennycook, A. (1995). English in the world/The world in English. In J. W. Tollefson (Ed.), Power and Inequality in Language Education (pp. 34-58). Cambridge: Cambridge University Press.

Pennycook, A. (1999a). Introduction: Critical Approaches to TESOL. TESOL Quarterly, 33(3), 329-

348.

Pennycook, A. (1999b). Development, Culture and Language: Ethical Concerns in a Postcolonial

World. In J. Shaw, D. Lubelska \& M. Noullet (Eds.), Partnership and Interaction: Fourth

International Conference on Language and Development, Hanoi, Vietnam. (pp. 3-22) Bangkok: Asian Institute of Technology.

Porter, P., \& Vidovich, L. (2000). Globalization and Higher Education Policy. Educational Theory, 50(4), 449-59.

Pratt, M. L. (1992). Imperial Eyes: Travel Writing and Transculturation. London: Routledge.

Pratt, M. L. (1999) Apocalypse in the Andes. Americas, 51(4), 38-47.

Pratt, M. L. (2002). Modernity and Periphery: Toward a Global and Relational Analysis. In E. Mudimbe-Boyi (Ed.), Beyond Dichotomies. Histories, Identities, Cultures and the Challenge of Globalization (pp. 21-48). Albany: State University of New York.

Rizvi, F. (2000). International Education and the Production of Global Imagination. In N. Burbules \&

C. Torres (Eds.), Globalization and Education. Critical Perspectives (pp. 205-206). New York,

London: Routledge.

Rushdie, S. (1982, July 3). The Empire writes back with a vengeance. The Times, p. 8.

Rushdie, S. (1983). Shame. New York: Alfred A. Knoff, Inc.

Shome, R., \& Hegde, R. (2002). Culture, Communication and the Challenge of Globalization. Critical Studies in Media Communication, 19(2), 172-189.

Singh, P (2004). Globalization and Education. Review Essay Educational Theory, 54(1),

Spack, R. (1997). The rhetorical construction of multilingual students. TESOL Quarterly, 31(4), 765774.

Spring, J. (2001). Globalization and Education Rights. An Intercivilizational Analysis. Mahwah, New Jersey: Lawrence Erlbaum Associates, Publishers.

Tomlinson, J. (1999). Globalization and Culture. Cambridge: Polity Press.

Waters, J. (2001). Globalization ( $2^{\text {nd }}$ Ed.), London: Routledge.

Yon, D. (2000). Elusive Culture: Schooling, Race, and Identity in Global Times. New York: State

University of New York Press.

Zamel, V. (1997). Toward a model of transculturation. TESOL Quarterly, 31(2), 341-352. 